\title{
油脂と健康
}

\section{Fat and Health}

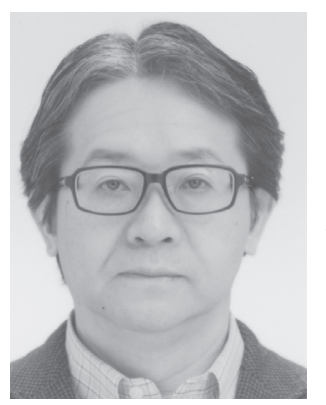

\author{
長岡 利 \\ 岐阜大学応用生物科学部 \\ T 501-1193 \\ 岐阜市柳戸 $1-1$
}

Satoshi NAGAOKA

Gifu University, Faculty of Applied Biological

Sciences

1-1 Yanagido, Gifu 501-1193, Japan

論文要旨：今回の総説は次のような $2 つ の$ 視点で構成されている。1. 油脂と健康, 2. 脂質代謝に影響す る食品成分であり，それぞれについて，主に心臓血管疾患，高脂血症，肥満に対する影響について概説した。 1. の概要は以下である。最近, 脂肪摂取の量的な面において, 総脂肪と飽和脂肪の摂取量を減らすことが 推奨されている。消費する脂肪の量よりも，脂肪の質に焦点を置くことがより効果的であると考えられ，特 に, 飽和脂肪摂取の減少と不飽和脂肪の摂取増加及び摂取エネルギーの制限を加味しての推奨が望ましいと 考えられている。そこで, 食事脂肪の質と疾病（特に心臓血管疾患）との関連性について, 飽和脂肪酸, 一 価不飽和脂肪酸, 多価不飽和脂肪酸, トランス脂肪酸などと心臓血管疾患との関連性について概説した。2. の概要は以下である。今回はヒト試験成績のあるタンパク質, ペプチド, アミノ酸を用いたコレステロール 代謝改善素材を中心に概説した。また，肥満と食品成分について，主にタンパク質やペプチドの機能性につ いて概説した。

\begin{abstract}
This review consists of two parts of the viewpoints. 1. Fat and health 2. Food components affecting lipid metabolism. Each chapter mainly represents the relationships between cardiovascular disease, hyperlipidemia, obesity and fat or food components respectively. Chapter 1: Current recommendations relating to quantitative fat intake call for a reduction in total fat and saturated fat intakes. It may be more effective to focus on qualitative fat consumption than that on quantitative fat consumption, notably, decreased saturated fat and increased unsaturated fat, combined with recommendations to restrict energy intakes. Thus, this review deals with the relationships between qualitative fat consumption and diseases, especially, cardiovascular disease, for example, the relationships between saturated fatty acids, monounsaturated fatty acids, polyunsaturated fatty acids, trans fatty acids and cardiovascular disease. Chapter 2: This review mainly represents the human study related to the ameliorative action of cholesterol metabolism induced by dietary protein, peptide, amino acid. Also, this review mainly deals with the anti-obesity action induced by dietary protein, peptide.
\end{abstract}

Key words: fat, cholesterol, cardiovascular disease, obesity, protein, peptide

\section{1 はじめに}

今回の総説は，次のような $2 つ の$ 視点で構成されてい る。1．油脂と健康，2．脂質代謝に影響する食品成分。 これらのそれぞれについて, 主に心臓血管疾患, 高脂血 症，肥満に対する影響に重点をおいて概説した。

連絡者: 長岡 利

E-mail : nagaoka@gifu-u.ac.jp

\section{2 油脂と健康}

\section{$2 \cdot 1$ 脂肪酸と疾病}

近年, 脂肪摂取の量的な面において, 総脂肪と飽和脂 肪の摂取量を減らすことが推奨されている ${ }^{1)}$ 。この推奨 の根拠は, 体重が炭水化物ではなく脂肪の摂取量と相関 性があるとする疫学的証拠である ${ }^{2)}$ 。さらに, 食事中の 脂肪量の増加は, 体内での脂肪の酸化よりも, むしろ脂 肪組織への蓄積が進むという研究成果がある ${ }^{3)}$ 。しかし, 
これまでの研究全てがそれを支持しているわけではな w。

たとえば, エネルギー％としての食事性脂肪の減少が,

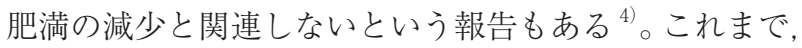
食事脂肪のエネルギー\%と, 肥満との関連性を示す十分 な研究デー夕はない ${ }^{5)}$ 。

これまで述べてきたように，脂質目安量の策定にまつ わる科学的根拠の不足から, 脂質の適正摂取についての 議論は多い。近年の推奨では, リノール酸の適正摂取量 は，2\%エネルギーとしている ${ }^{6)}$ 。 $\alpha$-リノレン酸の健康 的摂取量は $0.7 \%$ エネルギー, 冠動脈を健康に保つ EPA +DHA の最小摂取量は 1 日当たり $500 \mathrm{mg}$ としている。 心疾患予防の観点から, 欧米人でも実行可能な值として, n-6/n-3 比 6: 1 が推奨されている ${ }^{7)}$ 。米国では脂質の攝 取量に関する基本的な考え方を報告している ${ }^{8)}$ 。この報 告で適正摂取量が明示されているのは, n- 6 系及びn-3 系多価不飽和脂肪酸だけである。総脂肪, 飽和脂肪酸及 びモノ不飽和脂肪酸については科学的根拠が十分ではな いので，適正摂取量，推奨摂取量，許容摂取上限值は設 定されていない点は重要である。この点に関連し, 米国 では 2005 年に推奨值をより具体化し，総脂肪（20～ $35 \%$ エネルギー)，リノール酸（5～10％エネルギー）, $\alpha$-リノレン酸（0.6〜 $1.2 \%$ エネルギー）としている ${ }^{9)}$ 。

このような背景から，消費する脂肪の量よりも，脂肪 の質に焦点を置くことがより効果的であると考えられ， 特に, 飽和脂肪の減少と不飽和脂肪の増加及び摂取エネ ルギーの制限を加味しての推奨が望ましいと考えられて いる ${ }^{10)}$ 。

そこで，食事脂肪の質と疾病（特に心臓血管疾患）と の関連性について概説する。食事に含まれる多価不飽和 脂肪酸と他の脂肪酸の質に関連する疾病には, 以下のよ うなものが知られている。冠状動脈心疾患と梗塞, 乳幼 児期の必須脂肪酸欠乏症, 自己免疫疾患, 2 型糖尿尿病, 炎症性腸疾患, 乳癌, 大腸癌, 前立腺癌, 関節リウマチ などである。

飽和脂肪酸と心臓血管疾患については，飽和脂肪酸摂 取と血中総コレステロールと LDL- コレステロールを増 加させ，心臓血管疾患の危険性を増加させる ${ }^{11)}$ 。飽和 脂肪酸摂取量の減少は血中 LDL-コレステロールを減少 させるための中心的食事療法である ${ }^{12)}$ 。飽和脂肪酸か らのエネルギーに㧍ける 1\%増加における分析は, 0.033 〜0.045 mmol/L まで血中 LDL- コレステロールを増加 させ, $0.011 〜 0.013 \mathrm{mmol} / \mathrm{L}$ まで血中 HDL- コレステロー ルを増加させる ${ }^{13)}$ 。ステアリン酸を除く全ての長鎖飽 和脂肪酸は炭水化物と比べて, 血中 LDL- コレステロー ルや HDL- コレステロールを増加させる ${ }^{14)}$ 。ステアリン
酸は他の長鎖脂肪酸と比較して, 血中 LDL-コレステ ロールを増加させないので, コレステロールを増加させ る脂肪酸から除外された ${ }^{15)}$ 。臨床試験の結果は, 飽和 脂肪酸を不飽和脂肪酸で置換することが脂質代謝を改善 し，心臓血管疾患のリスクを減少させることが一貫して 示されている。たとえば, 飽和脂肪酸を多価不飽和脂肪 酸 ${ }^{16)}$ や一価不飽和脂肪酸 ${ }^{17)}$ で置換することは血中 LDL-コレステロールを減少させる。

一価不飽和脂肪酸と心臓血管疾患については, 飽和脂 肪酸の一価不飽和脂肪酸による置換が, 血中脂質を改善 することを支持する強い証拠がある ${ }^{11)}$ 。飽和脂肪酸の 一価不飽和脂肪酸による置換は, 血中 LDL-コレステ ロールを減少させることがヒト試験で報告されてい る $^{16,18)}$ 。一価不飽和脂肪酸と炭水化物の両方が, 飽和 脂肪酸と置換された場合は，血中 LDL-コレステロール は減少するが，炭水化物に対して一価不飽和脂肪酸は, 血中 HDL- コレステロールを増加できる ${ }^{19,20)}$ 。多価不 飽和脂肪酸よりも一価不飽和脂肪酸に富んだ食事の方 が, 血中 LDL 酸化に対する抵抗性がある可能性が示め されている ${ }^{19)}$ 。一価不飽和脂肪酸は多価不飽和脂肪酸 と比較して, 自動酸化を受けにくく, 血中での酸化物の 形成が少ない ${ }^{21-23)}$ 。

冠状動脈心疾患においては, n-3 と n-6脂肪酸の摂取は, 血中の総コレステロールと LDL- コレステロールを低下 させることが知られている。また, n-3 長鎖高度不飽和 脂肪酸である EPA や DHA を含む伝統的な食事（魚や 海獣が主食)を摂っているエスキモー人の報告 ${ }^{24)}$ がきっ かけで, n-3 系高度不飽和脂肪酸を摂取すると高脂血症 が改善されることが明らかにされている。たとえば，心 疾患を発症した人が魚もしくは, 魚油の n-3 系多価不飽 和脂肪酸（EPA や DHA）を摂取すると，心臓血管疾患 による死亡率や突然死が著減することが, 無作為化臨床 試験で報告されている ${ }^{25)}$ 。心臓血管疾患の死亡率と魚 の摂取との関連性は 22 万人以上を対象に平均 11.8 年間 にわたる追跡調査が行われた結果, 週に5 日以上魚を食 べる人は，ほとんど食べない人と比較して，心臓血管疾患 による死亡率が 38\%低下することが報告されている ${ }^{26)}$ 。 また， 1 週間に 5 皿以上の魚料理を食べる人は，月に 1 皿以下しか食べない人と比較して脳梗塞の危険性が $31 \%$ 低下することも報告されている ${ }^{27)}$ 。さらに, 日本 人を用いたヒト試験 (EPA とスタチン投与による大規 模試験）で，18,645 名の患者がブラバスタチン $10 \mathrm{mg} /$ 日または, シンバスタチン $5 \mathrm{mg} /$ 日のみ投与群 (対照群) と, これらのスタチンに加えて $1,800 \mathrm{mg} /$ 日の $\mathrm{EPA} を$ 投与する群 (スタチン + EPA 群) の 2 群に無作為に分 けられ， 4.5 年間以上追跡した結果，心臓由来の突然死， 
冠動脈障害，不安定狭心症，冠動脈バイパス術，冠動脈 形成術の発症は対照群と比較して, スタチン + EPA 群 において 19\%減少する ${ }^{28)}$ 。

一方, 植物由来の $\mathrm{n}-3$ 系多価不飽和脂肪酸の $\alpha$ リノレ ン酸は, 亜麻仁油, ナタネ油, ナッツ類, 豆類, 緑色野 菜に含まれる。疫学研究において, $\alpha$ リノレン酸の摂取 量または，血液や組織中の $\alpha$ リノレン酸の存在が心臓血 管疾患の発症に負の相関があることが示されている ${ }^{29)} 。$ しかし，心臓血管疾患を予防するために適切な $\alpha$ リノ レン酸摂取量を決定するための臨床研究は不十分であ る。また， $\alpha$ リノレン酸自体が心臓血管疾患に予防的に 働いているのか, $\alpha$ リノレン酸の代謝物が有益に働いて いるのかは不明である。 転換されるが，ヒトではこの転換比率は約 7\%であり ${ }^{30)}$, $\alpha$ リノレン酸から DHA への転換比率もヒトでは $1 \%$ 以 下 ${ }^{30)}$ や5\%以下 ${ }^{31)}$ である。

次にn-3 と n-6 脂肪酸の比については, 心藏血管疾患 の予防の観点から, 米国では, n-6/n-3 比 $=6: 1$ が推奨 されている ${ }^{32)}$ 。ただし，この場合にも，比率よりも必 須脂肪酸摂取量が過㮃にならないことが指摘されてい る。多価不飽和脂肪酸は, 一般に, 飽和脂肪酸やいくつ かの炭水化物の置換物として推奨されている。長鎖 $n-3$ 脂肪酸の摂取は血中 $\mathrm{EPA}+\mathrm{DHA}$ 濃度増加のための最も 効率的な方法であり, 心藏血管疾患の危険性の減少を導 く方法である。しかし，血中におけるn-3 変換を改善す るために, 利用可能な $\mathrm{n}-6$ 脂肪酸量を減少させることで は，心臓血管疾患に利益がある血中 $\mathrm{EPA}+\mathrm{DHA} レ$ レル に到達しない。だから, 心臟血管疾患の予防の観点から は, n-6 脂肪酸の減少より, むしろ長鎖 n-3 脂肪酸の増 加が推奨されている ${ }^{33)}$ 。

共役リノール酸の健康に対する影響について概説す る。共役リノール酸はリノール酸の位置・幾何異性体の 総称である。牛乳脂肪などに存在する天然の共役リノー ル酸は, 反菢動物の第一胃内に生息するButyrivibrio fibrisolves などのセルロース分解細菌が生物水素付加反 応の中間生成物として, 主にリノール酸を前駆物質とし て生成される ${ }^{34)}$ 。乳脂肪中の共役リノール酸（80〜 $95 \%$ は $c 9, t 11$ - 共役リノール酸: 天然型共役リノール酸) の含有量は数 $\mathrm{mg} / \mathrm{g}$ 脂質である。ヒトの食事からの共役 リノール酸摂取量は, $40 \mathrm{mg} /$ 日 $1.5 \mathrm{~g} /$ 日であり ${ }^{35)}$, そ の主な給源は乳製品である。また，アルカリ条件下での 加熱により調製した共役リノール酸（非天然型共役リ ノール酸）は， $c 9, t 11$ 共役リノール酸及び $t 10, c 12$ - 共 役リノール酸を約 $45 \%$, t 9,11 - 共役リノール酸及び $t 10 ， 12$ - 共役リノール酸を約 $5 \%$ 含む混合物である。

抗動脈硬化作用については, 非天然型共役リノール酸, $c 9, t 11$ 共役リノール酸, $t 10, c 12$ - 共役リノール酸の全 てで同程度の作用である。具体的には, 動物実験（ハム スター）において, 天然型共役リノール酸を強化したバ ターを含む高コレステロール食摂取により，通常のバ ターを含む高コレステロール食摂取の場合と比較して, 血漿 LDL- コレステロールが低下し, 脂質代謝改善作用 が認められる ${ }^{36)}$ 。ヒト試験において, 非天然型共役リノー ル酸を $0.7 〜 1.4 \mathrm{~g}$ /日摂取した場合, HDL-コレステロー ルが減少することが報告されている ${ }^{37)}$ 。一方, 共役リノー ル酸混合物 $(c 9, \quad t 11$ - 共役リノール酸 $: t 10, c 12$ - 共役リ ノール酸 $=50: 50 ） 3 \mathrm{~g} /$ 日の 8 週間摂取は，血清トリグ リセリドが有意に減少し，共役リノール酸混合物 $(c 9$, $t 11$ - 共役リノール酸 $: t 10, c 12$ - 共役リノール酸 $=80$ : 20） $3 \mathrm{~g} /$ 日の 8 週間摂取は, 血清 VLDL-コレステロー ルを有意に減少させる ${ }^{38)}$ 。一方, II 型糖尿病患者にお いて, 非天然型共役リノール酸 $(c 9, t 11$ - 共役リノール酸: t10, $c 12$ 共役リノール酸=50：50）の $3 \mathrm{~g} /$ 日摂取では, 血中グルコース濃度が有意に増加し，インスリン感受性 は減少し, HDL- コレステロールは有意に増加し, HDLコレステロールに対する LDL-コレステロールの比は有 意に低下することが報告されている ${ }^{39)}$ 。よって, 共役 リノール酸はヒトにおいて抗動脈硬化作用を発揮できる という結論には至っていない。

次に, トランス脂肪酸の健康に対する影響について概 説する。天然に存在する脂肪酸の多くは, シス型二重結 合を含む。これに対し, トランス型二重結合を持つ不飽 和脂肪酸の総称がトランス脂肪酸である。一方, コーデッ クス会議により, 食品の栄養表示に関するトランス脂肪 酸の定義は,「少なくとも1つのメチレン基によって離 されたトランス型の炭素 - 炭素二重結合がある不飽和脂 肪酸の全ての幾何異性体」であり，共役二重結合を持つ 共役リノール酸は含まない。よって, 牛や羊などの反媰 動物では胃中の微生物の働きによってトランス脂肪酸 (共役リノール酸) が作られるため, 牛肉, 羊肉, 牛乳・ 乳製品にも微量のトランス脂肪酸が含まれるが，これら は，以下に述べるWHO の規制の対象外である。

トランス脂肪酸の摂取に関しては, 国際的に, WHO の「食事, 運動と健康に関する世界戦略」（2004 年）で, 「脂肪由来のエネルギー摂取量を抑え, 脂肪消費の内容 を飽和脂肪酸から不飽和脂肪酸に変え, トランス脂肪酸 の除去を目指す」とされ, 食事, 栄養及び慢性疾患予防 に関する $\mathrm{WHO} / \mathrm{FAO}$ 合同専門家会合の報告書 (2003 年) では,「1日当たりの総エネルギー摂取量の $1 \%$ 未満とす る」という目標が示されている。米国では, 2006 年か ら加工食品中のトランス脂肪酸含有量の表示を義務化し た。一方, 日本人 1 日あたりの摂取量は, 食品安全委員 
会の調査では, 総エネルギー摂取量の $1 \%$ 未満になって いる ${ }^{40)}$ 。ただし, 脂質の多い食品の食べ過ぎなどの偏っ た食事の場合では，平均值を上回る摂取量となる可能性 がある。食事から最も多く摂取しているトランス脂肪酸 は，植物油の部分水素添加物（マーガリンなど）に含ま れるエライジン酸 $(\mathrm{C}: 18, t-18: 1)$ である。なお, 日 本では, 加工食品中のトランス脂肪酸含有量の表示は検 討中である。

トランス脂肪酸の摂取と心臓血管疾患との関連につい ては種々の研究が報告されている。たとえば, トランス 脂肪酸の摂取は血中 LDL- コレステロール濃度を上昇さ せ，HDL-コレステロール濃度を低下させ，炎症応答を 亢進することが報告されている ${ }^{41)}$ 。疫学研究や臨床研 究で, 一貫してトランス脂肪酸の摂取が心臓血管疾患の 危険性を増加させ，血中脂質に悪影響を及ぼすことが強 く示唆されている ${ }^{42,43)}$ 。トランス脂肪酸は, 飽和脂肪 酸を含む他の全ての脂肪酸と比較し, 血中脂質に対して 最も悪い影響を及ぼす。飽和脂肪酸とトランス脂肪酸は, いずれも LDL-コレステロールを増加させるが，トラン ス脂肪酸は飽和脂肪酸と比較して, より HDL-コレステ ロールを低下させる ${ }^{42)}$ 。臨床試験データの解析は, 卜 ランス脂肪酸の $2 \%$ 増加は, HDL-コレステロールに対 する LDL- コレステロールの比率を増加させ, 心臓血管 のリスクを $53 \%$ 増加させることを示唆する ${ }^{42)}$ 。

\section{3 脂質代謝に影響する食品成分}

\section{$3 \cdot 1$ 高脂血症と食品成分}

今回はヒト試験成績のあるタンパク質, ペプチド，ア ミノ酸を用いたコレステロール代謝改善素材を中心に解 説する。高コレステロール血症, 高脂血症, 動脈硬化症 予防・改善のための多くの医薬品・食品の登場, 社会的 関心とは裏腹に，現在でも WHO の統計では，世界の死 因の第 1 位は，依然として心臓血管疾患であり，決定的 な動脈硬化症の解決策は残念ながら現在もない, という のも厳然とした事実である。高コレステロール血症や高 脂血症の制圧は動脈硬化症制圧につながる。このような 背景から食物繊維, 大豆タンパク質などが研究されてき た ${ }^{44)}$ 。しかし，満足できる成分が発見されていないこ とは，上記の事実からも明白である。つまり，従来から 世界中で研究されてきた大豆タンパク質や食物繊維など の従来の食品や医薬品では, 高コレステロール血症や高 脂質血症の予防改善は実現困難である。また，そのため の理論・技術も未成熟である。したがって, コレステロー ル代謝や脂質代謝を改善するための革新的な理論・技術 が切望されている。このような視点から, コレステロー ル代謝改善や脂質代謝改善成分の研究が取り組まれてい
Table 1 特定保健用食品（コレステロールが高めの方の 食品）に利用されている成分

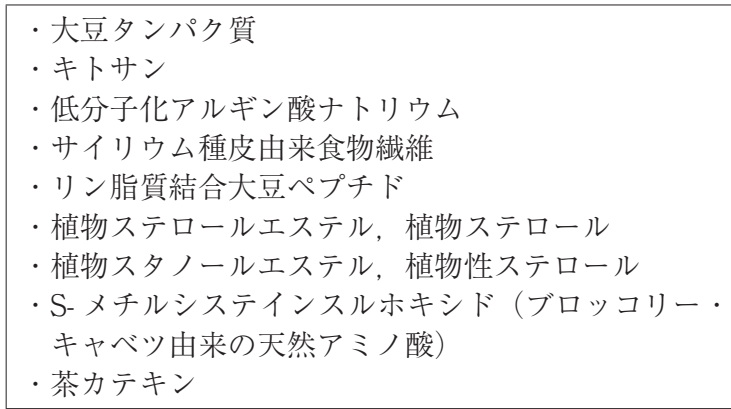

る。

大豆タンパク質を活用して, 大豆タンパク質そのもの や大豆タンパク質ペプシン分解物高分子画分よりも強力 に血清コレステロール低下作用を高めることが試みられ ている。そのための方策として, 大豆タンパク質と大豆 リン脂質を効率的に結合させ, 酵素分解し, リン脂質結 合大豆ペプチドが得られている。動物実験で, リン脂質 結合大豆ペプチドはコレステロール吸収抑制により血清 コレステロール低下作用を発現することが報告されてい る ${ }^{45)}$ 。高コレステロール血症者が 1 日わずか $3 \mathrm{~g}$ のリン 脂質結合大豆ぺプチドを 3 ケ月間摂取することにより， 血清コレステロールの有意な低下が観察されている ${ }^{46)}$ 。 これはFDA が示している大豆タンパク質そのものの効 果 (1日 $25 \mathrm{~g}$ 摂取) よりも極めて優れている。リン脂 質結合大豆ペプチドは特定保健用食品に許可されてい る。

また, 卵白タンパク質やその加水分解物摂取は高コレ ステロール食摂取ラットやマウスで血清コレステロール 低下作用を有することが報告されている ${ }^{47)}$ 。また，卵 白タンパク質は健康な女性ではコレステロール代謝に好 ましい影響をもたらすことが報告されている ${ }^{48)}$

アミノ酸では，ブロッコリーやキャベッに多く含まれ る天然アミノ酸である S-メチルシステインスルホキシ ド摂取により，ラットやヒトにおいて血清コレステロー ル低下作用を発揮することが報告されている ${ }^{49,50)}$ 。

その他の成分については, 誌面の関係で総説 ${ }^{44)}$ や別 の成書を参考にすることを扮勧めする ${ }^{51)}$ 。

\section{$3 \cdot 2$ 肥満と食品成分}

肥満と食品成分について，主にタンパク質やペプチド の機能性について概説する。肥満の治療に用いられる多 くのアプローチのうちのひとつは, 脂肪の吸収抑制であ る。その目的は, 天然の食事脂肪を容易に消化されない 素材で置き換えたり, 消化それ自身の過程を阻害する物 質を与えたりして, 食事脂肪由来のエネルギー割合を減 らすことである。医薬品の例では, オルリスタットであ 
Table 2 特定保健用食品（血中中性脂肪，体脂肪が気に なる方の食品）に利用されている成分



る。オルリスタットは, 化学合成されたリプスタチン(微 生物の産生物）の誘導体であり，脺リパーゼ活性を直接 阻害し, トリアシルグリセロールの消化を抑制し, 糞中 への脂質排泄を増加させ, 体脂肪を減少させるとともに, 血清脂質濃度を改善する ${ }^{52)}$ 。ただし, 種々の副作用も 報告されている ${ }^{53)}$ 。また, 膵リパーゼをニワトリに免 疫し, 抗リパーゼ卵黄抗体 (IgY) を調製する。抗リパー ゼ IgYは膵リパーゼをオルリスタットよりも強力に抑 制し，トリアシルグリセロールの消化を抑制し，糞中へ の脂質排泄を増加させ, マウスで体脂肪を減少させるこ とが報告されている ${ }^{54)}$ 。さらに，お茶に含まれるエピ ガロカテキンガレート ${ }^{55)}$ や黑ウーロン茶のポリフェノー ルなどの種々の食品成分が抗肥満作用を有することが報 告されている。

一方, 抗肥満作用を発揮するタンパク質やペプチドの 抗肥満作用も報告されている。具体的には, マウスの高 脂肪・高 $\mathrm{Ca}$ 食摂取において, 乳清タンパク質やその構 成タンパク質 $(\alpha-$ ラクトアルブミン,$\beta-$ ラクトグロブ リン）の摂取は抗肥満作用を発揮することが報告され, とくに $\alpha$-ラクトアルブミンは乳清タンパク質自身より も有効である ${ }^{56)}$ 。また, ラクトフェリンの抗肥満作用 が動物実験やヒト試験で報告されている。ラクトフェリ ン $100 \mathrm{mg}$ /日を 56 日間摂取で内藏脂肪が有意に減少す ることが報告されている。ラクトフェリンを前駆脂肪細 胞に添加した実験で，脂肪細胞における脂肪蓄積の低下は CCAT/enhancer 結合タンパク質 $\alpha$ やPPAR $\gamma$ の mRNA レベルの低下と関連することが報告されている ${ }^{57) 。 ま た, ~}$ 大豆タンパク質中に $\beta$ - コングリシニンは約 $20 \%$ 存在す るタンパク質であり， $\alpha^{\prime}, \alpha, \beta$ の 3 種類のサブユニッ トから構成されている。ヒトでは 1 日， $5 \mathrm{~g}$ の $\beta$-コング リシニン摂取により内臓脂肪が減少すると報告 ${ }^{58)}$ され, 特定保健用食品に許可されている。 $\beta$ - コングリシニン は肝臓での脂肪の燃焼（ $\beta$-酸化）を促進し, 脂肪の再 合成を抑制する効果があり, さらに糞中への脂肪の直接
排泄を促進するという相乗効果により血中中性脂肪を低 下させる働きがあると考えられる。また, 動物実験 ${ }^{59)} や$ ヒト試験 ${ }^{60)}$ において，食後の中性脂肪の上昇を抑制す るペプチドとして，グロビン蛋白分解物が報告されてい る。グロビン蛋白分解物に含まれるオリゴペプチドから, 食後の中性脂肪上昇を抑える作用をもつ 3 種類のオリゴ ペプチドVVYP, VYP, VTLが分離され，ラットなど の動物実験により, なかでもVVYPは最も強い作用を 示すことが報告 ${ }^{59)}$ され，特定保健用食品に許可されて いる。

\section{文 献}

1) Grundy, S. M.; Denke, M. A. J. Lipid Res. 31, 1149-1172 (1990).

2) Lissner, L.; Heitman, B. Eur. J. Clin. Nutr. 49, 79-90 (1995).

3) Jequier, E. News Physiol. Sci. 8, 273-276 (1993).

4) Willett, W. C. Am. J. Clin. Nutr. 67S, 556S-562S(1998).

5) Seidell, J. C. Am. J. Clin. Nutr. 67S, 546S-550S (1998).

6) ISSFAL Newsletter $11: 12-25$ (2004).

7) Wijendran, V.; Hayes, K. C. Ann. Rev. Nutr. 24, 597615 (2004).

8) Trumbo, P. et al. J. Am. Diet. Assoc. 102, 1621-1630 (2002).

9) National Academies press, Washington DC, pp.422-541 (2005).

10) Lichtenstein, A. H. J. Womens Health 12, 109-114 (2003).

11) DGAC, Report of the Dietary Guidelines Advisory Committee on the Dietary Guidelines for Americans (2010).

12) Lichtenstein, A. H. et al. Circulation 114, 82-896(2006).

13) Hegsted, D. M. et al. Am. J. Clin. Nutr. 57, 875-883 (1993)

14) Mensink, R. P. et al. Am. J. Clin. Nutr. 77, 1146-1155 (2003).

15) DGAC, Dietary Guidelines for Americans (2010).

16) Lichtenstein, A. H. et al. Am. J. Clin. Nutr. 84, 497-504 (2006).

17) Berglund, L. et al. Am. J. Clin. Nutr. 86, 1611-1620 (2007).

18) Yu-Poth, S. et al. J. Nutr. 130, 2228-2237 (2000).

19) Garg, A. Am. J. Clin. Nutr. 67, 577S-582S (1998).

20) Mensink, R. P. et al. Am. J. Clin. Nutr. 77, 1146-1155 (2003).

21) Ashton, E. L. et al. J. Am. Coll. Nutr. 20, 320-326 (2001).

22) Hargrove, R. L. et al. J. Nutr. 131, 1758-1763 (2001).

23) Ahuja, K. D. et al. Clin. Sci. 105, 355-361 (2003).

24) Bang, H. O.; Dyerberg, J. Acta Med. Scand. 192, 85-94 (1972).

25) Marchioli, R. et al. Circulation 105, 1897-1903 (2002).

26) He, K. et al. Circulation 109, 2705-2711 (2004).

27) He, K. et al. Stroke 35, 1528-1542 (2004). 
28) Yokoyama, M.; Origasa, H. Am. Heart J. 146, 613-620 (2003)

29) Mozaffarian, D. et al. Circulation 111, 157-164 (2005).

30) Goyens, P. L. et al. J. Lipid Res. 46, 1474-1483 (2005).

31) Brenna, J. T. et al. Curr. Opin. Clin. Nutr. Metab. Care 5, 127-132 (2002).

32) Wijendran, V.; Hayes, K. C. Ann. Rev. Nutr. 24, $597-$ 615 (2004).

33) Harris, W. S. Curr. Atheroscler. Rep. 8, 453-459 (2006).

34) Palmquist, D. L. et al. Adv. Food Res. Nutr. 50, 179217 (2005).

35) Ritzenthalaer, K. L. et al. J. Nutr. 131, 1548-1554 (2001).

36) Lock, A. L. et al. J. Nutr. 135, 1934-1939 (2005).

37) Mougios, V. et al. J. Nutr. Biochem. 12, 585-594(2001).

38) Noone, E. J. et al. Br. J. Nutr. 88, 243-251 (2002).

39) Moloney, F. et al. Am. J. Clin. Nutr. 80, 887-895(2004).

40) Yamada, M. et al. J. Epidemiol. 20, 119-127 (2010).

41) Mozaffarian, D. et al. Eur. J. Clin. Nutr. 63 (Suppl 2), S5-21 (2009).

42) Ascherio, A. et al. N. Engl. J. Med. 340, 1994-8 (1999).

43) Oomen, C. M. et al. Lancet 357, 746-751 (2001).
44) Kerckhoffs, D. A. et al. J. Nutr. 132, 2494-2505 (2002).

45) Nagaoka, S. et al. J. Nutr. 129, 1725-1730 (1999).

46) Hori, G. et al. Biosci. Biotechnol. Biochem. 65, 72-82 (2001).

47) Yamamoto, S. et al. Nutr. Res. 13, 1453-1457 (1993).

48) Asato, L. et al. J. Nutr. Sci. Vitaminol. 42, 87-96 (1996).

49）小林民代ほか。日本栄養食糧学会誌 55, 275-280 (2002).

50) Suido, H. et al. Functional Food and Health, ACS, p.454-464 (2008).

51）医用機能性食品ガイドブック，医歯薬出版（2012）.

52) Hutton, B.; Fergusson, D. Am. J. Clin. Nutr. 80, 14611468 (2004).

53) Filippatos, T. D. et al. Drug Saf. 31, 53-65 (2008).

54) Hirose, M. et al. Nutr. Metab. 10, 70 (2013).

55) Grove, K. A. et al. Obesity 20, 2311-2313 (2012).

56) Pilvi, T. K. et al. Br. J. Nutr. 102, 337-41 (2009).

57) Ono, T. et al. Br. J. Nutr. 104, 200-211 (2010).

58) Kohno, M. et al. J. Atheroscler. Thromb. 13, 247-255 (2006).

59) Kagawa, K. et al. Life Sci. 58, 1745-1755 (1996).

60) Kagawa, K. et al. J. Nutr. 128, 56-60 (1998). 